\title{
Acute and specific impairment of spermatogonial development by GnRH antagonist-induced gonadotrophin withdrawal in the adult macaque (Macaca fascicularis)
}

\author{
Y. Zhengwei ${ }^{1}$, N. G. Wreford ${ }^{2}$, S. Schlatt ${ }^{2}$, G. F. Weinbauer ${ }^{3}$, \\ E. Nieschlag ${ }^{3}$ and R. I. McLachlan ${ }^{1 *}$ \\ ${ }^{1}$ Prince Henry's Institute of Medical Research, Monash Medical Centre, Melbourne, Australia; \\ ${ }^{2}$ Institute of Reproduction and Development, Monash University, Melbourne, Australia; and \\ ${ }^{3}$ Institute of Reproductive Medicine of the University, Domagkstrasse 11, D-48129 Münster, Germany
}

\begin{abstract}
This study examined the effect of $\mathrm{GnRH}$-antagonist ( $\mathrm{GnRH}-\mathrm{A}$ )-induced gonadotrophin withdrawal on numbers of germ cells in adult cynomolgus monkeys and aimed to identify the site of the earliest spermatogenic lesion(s) produced. Animals received either GnRH-A (Cetrorelix; $450 \mu \mathrm{g} \mathrm{kg}^{-1}$ day $^{-1}$ s.c.; $n=5$ ) or vehicle (control, $n=4$ ) for 25 days. One testis was removed on day 16 and the other testis on day 25. The optical disector stereological method was used to estimate germ and Sertoli cell numbers per testis. After GnRH-A treatment for 16 days, the number of type A spermatogonia was unchanged; however, type B spermatogonia ( $15 \%$ of control), preleptotene + leptotene + zygotene (15\% control) and pachytene $(55 \%$ control) spermatocytes were all reduced $(P<0.05)$. By day 25 , these cells were further reduced together with step 1-6 spermatids $(38 \%$ control; $P<0.05)$. More mature germ cells were unaffected. The proportion of type $A$ pale spermatogonia at stages VII-XII was reduced $(P<0.05)$ in GnRH-A-treated groups ( $52 \%$ on day $16,43 \%$ on day 25$)$ compared with control $(67 \%)$. After 25 days of GnRH-A treatment, the number of Sertoli cells was unaltered but nuclear volume was reduced $(66 \%$ control, $P<0.05)$. Tubule length was unchanged but volume $(50 \%$ control), diameter $(62 \%$ control) and epithelial thickness $(59 \%$ control) were reduced $(P<0.05)$. GnRH-A treatment suppressed serum testosterone concentrations into the castrate range, and testicular testosterone concentrations to $21-36 \%$ of control values. Serum inhibin (as an index of FSH action) was suppressed in GnRH-A-treated animals by day 16, declining to $38 \%$ of control concentrations at day 25. Therefore, the primary lesion produced by GnRH-A induced gonadotrophin withdrawal is the rapid and profound reduction in the number of type $B$ spermatogonia. The time course of germ cell loss suggests the inhibition of type A pale spermatogonial mitosis as the primary mechanism. Later germ cell maturation, specifically meiosis and spermiogenesis, appears to proceed unaffected. The decline in late spermatocytes and spermatids by 25 days of GnRH-A treatment is attributed to a 'depletional wave' from the spermatogonial lesion. The fact that such marked spermatogenic disruption occurs in the face of substantial testicular testosterone concentrations implies a significant role for FSH in spermatogonial development.
\end{abstract}

\section{Introduction}

Since the early reports that hypophysectomy suppressed spermatogenesis in rats (Smith, 1930) and monkeys (Smith, 1944), numerous studies have failed to resolve major issues in the hormonal regulation of spermatogenesis, particularly the roles of the major endocrine regulators: $\mathrm{FSH}$ and $\mathrm{LH}$ (LH acting via the stimulation of testosterone secretion by Leydig cells:

*Correspondence.

Received 10 April 1997.
McLachlan et al., 1996; Sharpe, 1994). While spermatogenesis has been reported in mice lacking the FSH $\beta$ gene (Kumar et al, 1997) and in men with inactivating mutations of the FSH receptor (Tapanainen et al., 1997), quantitatively normal spermatogenesis in men appears to require both gonadotrophins (Matsumoto et al., 1986). Possible reasons for the lack of consensus include differences between species, the specifics of the experimental paradigms and the approaches used to describe changes in germ cell development.

The non-human primate model of human spermatogenesis (Weinbauer et al., 1984, 1987, 1988, 1989, 1991, 1992, 1994; 
Akhtar ef al., 1985; Weinbauer and Nieschlag, 1985, 1993; Adams et al., 1986; Marshall et al., 1986a, b, 1995; Bremner et al., 1991) provides a means of assessing the effects of hormonal treatments for developing human contraceptive strategies (for example, using GnRH analogues) and for designing interventions aimed at protecting spermatogenesis from radio-chemotherapeutic damage (Kangasniemi et al., 1995). Exogenous testosterone treatment, with or without co-administration of a GnRH antagonist (GnRH-A), is a promising male contraceptive strategy; however, the inconsistent induction of azoospermia has not been explained and may limit its widespread application (Bagatell et al., 1993; WHO, 1990; Andersen and $\mathrm{Wu}, 1996)$. Furthermore, the site(s) of spermatogenic interruption during such treatment has not been well described.

Previous studies aimed at defining the site of spermatogenic interruption after gonadotrophin withdrawal in primates have been limited in number and have used either qualitative descriptions of the disruption of spermatogenesis or quantitative approaches based on older methods subject to bias. This bias derives from the need to make assumptions regarding the shape and size of the nuclei, and the failure to account for changes in the size of the reference compartments (for example, interstitium and tubules). Such assumptions are inevitable when expressing germ cell number in terms of a two-dimensional parameter such as per Sertoli cell nuclear profile or per tubule cross-section. The stereological literature provides the scientific basis for appreciating the origins of bias in earlier approaches (Sterio, 1984; Gundersen et al., 1988a; Wreford, 1995). The estimation of total numbers of germ cells during the manipulation of gonadotrophin concentrations can be used to identify sites of hormone action and has proved useful in identifying the sites of androgen action in rat spermiogenesis (O'Donnell et al., 1994). A major advance in the field of stereology has been the development of new approaches such as the optical disector method (Gundersen et al., 1988a), which is an efficient and, above all, an unbiased method involving no assumptions regarding number of Sertoli cells, or the shape and size of germ cells or tubuies (Wreford, 1995).

Chronic gonadotrophin deficiency in primates results in severe regression of the epithelium with essentially only type A spermatogonia being seen (Marshall et al., 1986b). GnRH-A treatment suppresses serum inhibin, FSH and LH concentrations and reduces serum testosterone to near castrate concentrations in primates (Adams et al., 1986; Weinbauer et al., 1991, 1992, 1994). In animals treated with GnRH-A for 4-50 weeks, the number of pachytene spermatocytes and spermatids declined markedly until only Sertoli cells, spermatogonia and few, if any, later germ cell forms were seen (Akhtar et al., 1985; Adams et al., 1986; Weinbauer et al., 1987, 1988, 1991). However, the process by which this regression occurs is unclear and data on the effects of acute gonadotrophin withdrawal are limited. As a result, it is uncertain whether single or multiple lesions as is the case in rats, are produced (McLachlan et al, 1996).

The present study used the optical disector approach for estimating the total number of germ cells, thus facilitating the assessment of the effects of acute gonadotrophin withdrawal on primate spermatogenesis. A rapid and profound fall in type B spermatogonia was observed, probably due to the inhibition of type A pale spermatogonial mitosis. However, no evidence was found for spermatogenic lesions at other sites.

\section{Materials and Methods}

\section{Animals}

Ten adult cynomolgus monkeys (Macaca fascicularis), weighing $5-6 \mathrm{~kg}$, were housed in individual cages under defined conditions as described by Weinbauer and Nieschlag (1993). They were fed standard monkey pellet food supplemented with fresh fruit. The study was undertaken in accordance with German Federal Law on the Care and Use of Laboratory Animals (License 72/92).

\section{Study design}

Animals received daily s.c. injections of vehicle (control, $n=5$ ) or the GnRH-A (Cetrorelix $450 \mu \mathrm{g} \mathrm{kg}^{-1}, n=5$ ) for 25 days. On day 7 , all animals received a single dose of bromodeoxyuridine for a later study of DNA synthesis and cell cycle dynamics to be reported elsewhere (Weinbauer et al., in press). On day 16, one testis was removed under general anaesthesia and the remaining testis was removed 9 days later (on day 25 of treatment) with data from these groups being described as A-16 and A-25, respectively. All testes were immersion-fixed in Bouin's fluid. Two serum samples were obtained during the pretreatment phase, and then on days 7 , 16,21 and 25 of treatment.

\section{Control group data}

Stereological data from the testes of vehicle-treated (control) animals on day 16 only were considered as the control for the study. The data from the other testis, removed on day 25 (that is, 9 days after hemicastration), were considered separately because of concern that endocrine and germ cell changes may have occurred after hemicastration. Subsequent analysis showed no significant differences in: testicular mass, volume fraction of the tubule and its lumen, stage frequency, tubule diameter, number or nuclear volume of Sertoli cells, or the total numbers of germ cells in any category (data not shown).

Both testes from one control animal were markedly reduced in size ( $8.2 \mathrm{~g}$ versus $17.2 \pm 2.0 \mathrm{~g}$ in the remaining four animals) and showed severe focal spermatogenic lesions. Total numbers of germ cells and Sertoli cells were less than half those of the remaining control animals. Consequently all data from this animal were excluded from subsequent analyses.

\section{Tissue processing}

Two tissue blocks were sampled randomly from each testis, processed and embedded in hydroxyethyl-methacrylate resin (Technovit 7100; Kulzer and Co., Friedrichsdorf) according to the manufacturer's instructions. Thick $(25 \mu \mathrm{m})$ sections were cut with a large surface area (approximately $60 \mathrm{~mm}^{2}$ ) using a Supercut microtome (Reichert Jung 2050; Nussloch), and 
stained with PAS (periodic acid-Schiff's reagent) and counterstained with haematoxylin.

\section{Cell identification and groupings}

All sections were coded, randomized and counted blind. Germ cells and Sertoli cells were identified on the basis of their nuclear morphology (Clermont and Leblond, 1955, 1959; Clermont, 1969). Germ cells were grouped as follows: type $A$ dark (Ad) spermatogonia; type A pale (Ap) spermatogonia; type B (BI-B4) spermatogonia; preleptotene + leptotene + zygotene primary spermatocytes; pachytene primary spermatocytes; secondary spermatocytes; round spermatids in steps 1-6; elongating spermatids in steps 7-12; and, elongated spermatids in steps 13-14. Ap spermatogonia were counted separately in stages I-VI and stages VII-XII. Late (step 13-14) spermatids, which were abnormally retained within the epithelium of stages VII-XII tubules in GnRH-Atreated animals, were counted separately.

\section{Stereological analysis}

Number of cells. Numbers of germ cells and Sertoli cells were estimated by counting directly in the thick sections according to the optical disector principle (Sterio, 1984; Gundersen et al., 1988a). Wreford (1995) has discussed this approach in application to the testis generally and McLachlan et al. (1995) have discussed it in relation to the rat testis. The optical disector stereological method is an unbiased and efficient technique for estimating numbers of cells, including nonspherical objects such as elongated spermatids, and assumes only that cell number equates to nuclear number. On average, a total of 1200 celis were counted per testis, with at least 100 cells in each category per testis. This provided an adequate sample size when performed in conjunction with the systematic uniform random sampling procedure used here (Gundersen et al., 1988b).

Stage frequency. Tubule staging was performed according to the criteria described by Clermont (1969) and Clermont and Leblond (1955, 1959). The frequency (proportion) of tubule profiles in stages I-VI and VII-XII was determined using a $\times 10$ (control and A-16 groups) or $\times 20$ (A-25 group) objective lens in conjunction with a $\times 10$ eyepiece fitted with a graticule on which a counting frame was marked. Where necessary, staging was confirmed at higher magnification. Tubule profiles that included a lumen were counted according to the unbiased counting rule described by Gundersen (1977). When a transitional zone between stages VI and VII or between stages XII and I was seen, each stage was ascribed half a profile. An average of 115 tubule profiles were counted per testis.

Assessment of type A pale spermatogonial mitoses in stages VII-XII. According to a model of Ap spermatogonial renewal in primates, Ap spermatogonia undergo two mitotic divisions to generate type $B$ spermatogonia: the first in stage VII and, in half of these Ap spermatogonia, a second in stage IX to produce type B spermatogonia (Clermont and Antar, 1973;
Fouquet and Dadoune, 1986). Consistent with this model, in control animals, approximately $65 \%$ of all Ap spermatogonia were predicted to be in stage VII-XII tubules, and the inhibition of Ap mitosis was predicted to result in a reduction in this proportion to approximately $54 \%$ (representing the relative duration of stages VII-XII). Thus, the proportion of Ap spermatogonia in stages VII-XII in all groups was determined to assess GnRH-A effects on Ap mitosis.

Nuclear volume of Sertoli cells. This was determined using the stereological approach of local vertical sections (Baddeley et al., 1986) according to the unbiased and efficient stereological principle of the rotator (Jensen and Gundersen, 1993). Forty Sertoli cell nuclei were sampled (from the vertical segment of the seminiferous tubule using the optical disector; Sterio, 1984) and measured per testis.

Parameters of seminiferous tubule structure. Seminiferous tubule and luminal volumes were determined by multiplying their respective volume fractions by the reference volume of the testis (Meachem et al., 1996). Tubule diameter was obtained by measuring the (short) axis of round or elliptical tubules with a clear lumen, sampled according to the uniform sampling rule described by Gundersen (1977). Total length of the tubule per testis was determined by dividing the total volume of the tubule per testis by the cross-sectional area of the tubule, assuming the tubule to be a cylinder. The mean diameter of the tubule lumen was calculated from the luminal volume and the tubule length, also assuming the lumen to be a cylinder. The average thickness of the seminiferous epithelium was calculated from the tubule and luminal diameters, assuming the lumen to be centrally placed in the tubule.

\section{Hormone determination}

Serum testosterone was measured by radioimmunoassay using a commercial kit (DSL-4100; Diagnostic Systems Laboratories, Sinsheim). Intra- and interassay coefficients of variation $(\mathrm{CV})$ were $6.5 \%$ and $13.4 \%$, respectively, and the detection limit was $0.17 \mathrm{nmol} \mathrm{l}^{-1}$. Testicular testosterone concentrations were measured by using the same radioimmunoassay reagents as described by Chandolia et al. (1991) in a single assay. The intra-assay CV was $5.1 \%$ and the detection limit was $0.68 \mathrm{nmol} \mathrm{l}^{-1}$. Serum inhibin was measured using a heterologous radioimmunoassay, using the no.1989 antisera as described by Fingscheidt et al. (1989) and Weinbauer et al. (1994) which detects forms containing the $\alpha$ subunit, including inhibin B and the pro $\alpha$-C protein. Human recombinant inhibin was used as standard. All samples were assayed in duplicate in a single assay. The detection limit was $1.2 \mathrm{ng} \mathrm{ml}^{-1}$ of serum and the intra-assay $\mathrm{CV}$ was $4.7 \%$. Data are expressed as a percentage of the mean pretreatment concentration of each animal.

\section{Statistical analyses}

All data are shown as mean \pm SEM. Multiple comparisons of stereological endpoints or testicular testosterone concentrations among different treatment groups were performed 
Table 1. The effect of GnRH-antagonist (GnRH-A)-induced gonadotrophin withdrawal on parameters of testicular structure in adult cynomolgus monkeys after 16 and 25 days

\begin{tabular}{|c|c|c|c|}
\hline Parameter & Control & $\begin{array}{l}\text { GnRH-A } \\
\text { (16 days) }\end{array}$ & $\begin{array}{l}\text { GnRH-A } \\
\text { (25 days) }\end{array}$ \\
\hline Testicular volume $\left(\mathrm{cm}^{3}\right)$ & $17.2 \pm 2.5$ & $14.3 \pm 1.8$ & $11.1 \pm 2.2^{*}$ \\
\hline Tubule volume per testis $\left(\mathrm{cm}^{3}\right)$ & $13.3 \pm 2.3$ & $10.2 \pm 1.4$ & $6.7 \pm 1.8^{a}$ \\
\hline Luminal volume per testis $\left(\mathrm{cm}^{3}\right)$ & $0.57 \pm 0.16$ & $0.51 \pm 0.13$ & $0.35 \pm 0.09$ \\
\hline Tubule diameter $(\mu \mathrm{m})$ & $228 \pm 8$ & $183 \pm 10^{\mathrm{a}}$ & $142 \pm 9^{\mathrm{ab}}$ \\
\hline Tubule length per testis (m) & $318 \pm 50$ & \pm 56 & \pm 72 \\
\hline Luminal diameter $(\mu \mathrm{m})$ & \pm 4 & \pm 5 & $\pm 4^{\mathrm{a}}$ \\
\hline Thickness of seminiferous epithelium $(\mu \mathrm{m})$ & \pm 4 & $77 \pm 3^{a}$ & $\pm 4^{\mathrm{ab}}$ \\
\hline
\end{tabular}

${ }^{a}$ Significantly different from control $(P<0.05)$; ${ }^{b}$ significantly different from GnRH-A-treated (for 16 days) group $(P<0.05)$; $* P=0.058$ compared with control.

using a one-way ANOVA (analysis of variance) in conjunction with the Student-Newman-Keuls method for individual comparisons. Multiple comparisons of serum inhibin or testosterone concentrations between different time points in either the control or GnRH-A-treated groups were performed using a one-way repeated measures ANOVA. A Student's $t$ test was used to assess serum inhibin and testosterone concentrations at particular time points between vehicle and GnRH-A-treated groups.

\section{Results}

\section{Parameters of testicular structure}

Testicular volume and the total volume of tubules per testis were unchanged in the A-16 group but declined in the A-25 group to $65 \%(P=0.058)$ and $50 \%(P<0.05)$ of control values, respectively (Table 1 ). The volume of tubule lumen and the total length of tubules were unchanged. However, tubule diameter and the thickness of the seminiferous epithelium fell significantly in both the A-16 (80\% and $83 \%$ of control) and A-25 (62\% and $59 \%$ of control) groups.

\section{Number of germ cells}

In neither GnRH-A-treated groups were there significant changes in numbers of type Ad, Ap or total type A spermatogonia compared with control (Fig. 1). However, there was a dramatic and consistent reduction in the numbers of type $B$ spermatogonia (to $15 \%$ of control) and preleptotene + zygotene + leptotene spermatocytes ( $15 \%$ control) in the A-16 group, which was even more marked in the A-25 group. The number of pachytene spermatocytes was significantly reduced to $55 \%$ and $13 \%$ of control in the A-16 and A-25 groups, respectively. Early round (step 1-6) spermatid number was not reduced in the A-16 group but was significantly reduced to $38 \%$ of control in the A-25 group. No significant change was seen in the numbers of step 7-12 or step 13-14 spermatids in the A-16 or A-25 groups (Fig. 1).

The progressive reduction in number of germ cells at and beyond the type $\mathrm{B}$ spermatogonial stage have been demon- strated by expressing germ cell numbers in the A-16 and A-25 groups as a percentage of control using a time scale reflecting the duration of spermatogenesis (Fig. 2). This progressive loss of germ cell numbers can also be observed under light microscopy (Fig. 3).

Very few late (step 13-14) spermatids were retained within the seminiferous epithelium at stage VII-XII in control animals. However, after GnRH-A treatment, $2.8 \pm 1.9 \%$ and $9.2 \pm 1.5 \%$ of the total step 13-14 spermatids were seen in these stages (especially stages VII-IX) in the A-I6 and A-25 groups, respectively.

\section{Relative number of type A pale spermatogonia and stage frequency in stages VII-XII}

The frequency of stage VII-XII tubules was $51.4 \pm 2.4 \%$ in control, which was unchanged after $\mathrm{GnRH}-\mathrm{A}$ treatment in A-16 (51.4 $\pm 2.6 \%)$ and A-25 (48.5 $\pm 1.6 \%)$ groups. The proportion of Ap spermatogonia at stage VII-XII in control animals $(67.0 \pm 5.8 \%)$ was significantly reduced in the A-16 $(52.2 \pm 3.3 \%)$ and $A-25(42.8 \pm 3.1 \%)$ groups.

\section{Sertoli cell parameters}

The number of Sertoli cells showed no significant change after GnRH-A treatment $(460 \pm 59,494 \pm 68$ and $627 \pm 120 \times 10^{6}$ per testis in control, A-16 and A-25 groups, respectively). The nuclear volume of Sertoli cells was $378 \pm 17 \mu \mathrm{m}^{3}$ in controls. This was unchanged in the A-16 group $\left(351 \pm 22 \mu \mathrm{m}^{3}\right.$ ) but was significantly reduced to $66 \%$ of control in the A-25 group $\left(249 \pm 14 \mu^{3}{ }^{3}\right)$.

\section{Serum and testicular testosterone concentrations}

Pretreatment serum testosterone concentrations were $32.5 \pm 11.5 \mathrm{nmol} \mathrm{l}^{-1}$ in the control group and $20.7 \pm 4.0 \mathrm{nmol}$ $\mathrm{1}^{-\mathrm{I}}$ in the GnRH-A-treated group (NS). Mean control testosterone concentrations ranged from 18.9 to $32.5 \mathrm{nmol} \mathrm{l}^{-1}$ throughout the study and showed no significant changes at any time point. GnRH-A treatment significantly reduced serum testosterone concentrations to $6.1 \pm 1.7 \mathrm{nmol} \mathrm{l}^{-1}(32 \%$ 

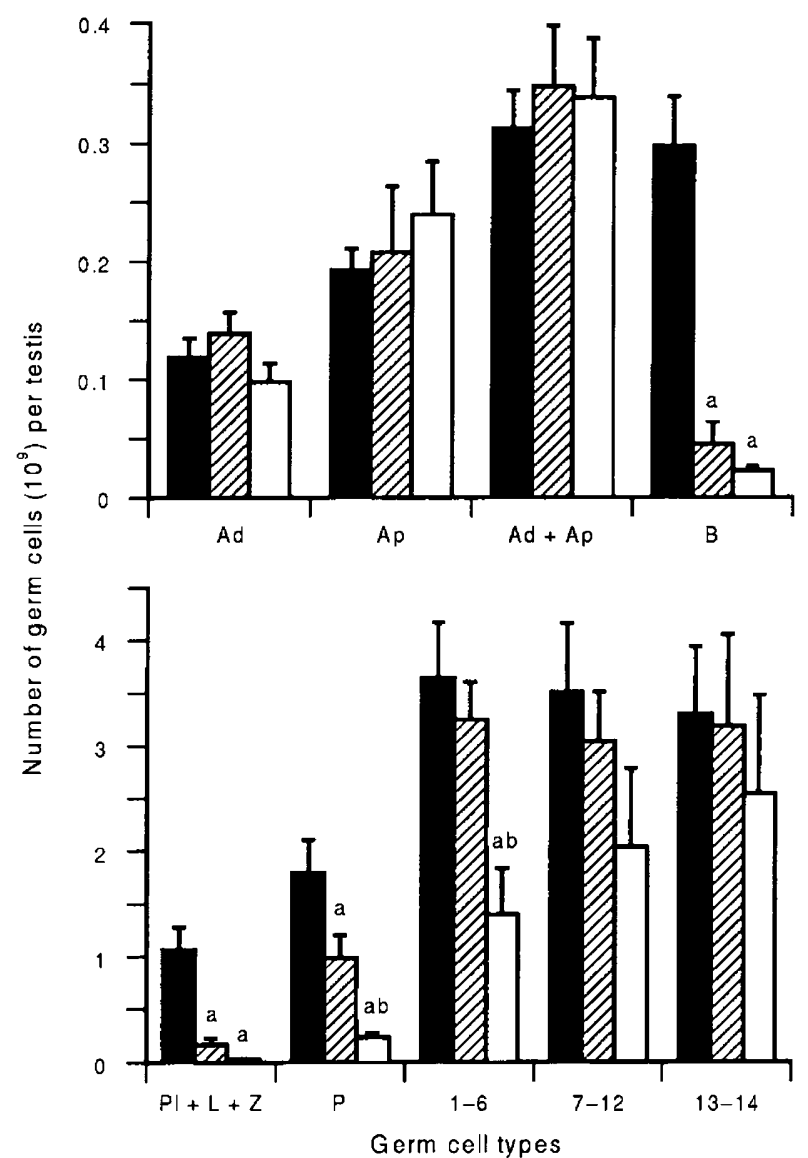

Fig. 1. Absolute number of germ cells ( $10^{9}$ per testis) in macaques receiving vehicle ( $\mathbf{\square})$, or $\mathrm{GnRH}$ antagonist for 16 days (ש) or 25 days ( $\square$ ). Ad, dark type A spermatogonia; Ap, pale type A spermatogonia; $B$, type $B$ spermatogonia; $\mathrm{Pl}+\mathrm{L}+\mathrm{Z}$, preleptotene, leptotene and zygotene primary spermatocytes; $P$, pachytene primary spermatocytes; $1-6$, step $1-6$ spermatids; $7-12$, step $7-12$ spermatids; $13-14$, step 13-14 spermatids. ${ }^{\text {a }} P<0.05$ compared with vehicle-treated group; ${ }^{b} P<0.05$ compared with $\mathrm{GnRH}$ antagonist-treated (for 16 days) group.

pretreatment) and $2.8 \pm 0.5 \mathrm{nmol} 1^{-1}$ ( $16 \%$ pretreatment) by day 7 and 25, respectively (Fig. 4). Mean testicular testosterone concentrations were $58.3 \pm 32.1,12.4 \pm 2.5$ and $20.8 \pm 9.7 \mathrm{ng}$ $\mathrm{g}^{-1}$ in control, A-16 and A-25 groups, respectively. However, neither treatment group was significantly below control.

\section{Serum inhibin concentrations}

The pretreatment serum inhibin concentrations in control and GnRH-A-treated animals were $7.7 \pm 2.4$ and $9.4 \pm 2.6 \mathrm{ng}$ $\mathrm{ml}^{-1}$, respectively (not significant). Inhibin concentrations then fell significantly by day 16 in both the control and GnRH-Atreated groups. As a percentage of the mean pretreatment value, serum inhibin concentrations were significantly lower in GnRH-A-treated than in control animals by day 16. By day 25 (9 days after hemicastration), serum inhibin concentrations were $3.9 \pm 1.3 \mathrm{ng} \mathrm{ml}^{-1}(49 \%$ of pretreatment) in control animals and $1.5 \pm 0.2 \mathrm{ng} \mathrm{ml}^{-1}$ (19\% of pretreatment and $38 \%$ of control) in GnRH-A-treated animals (Fig. 4).

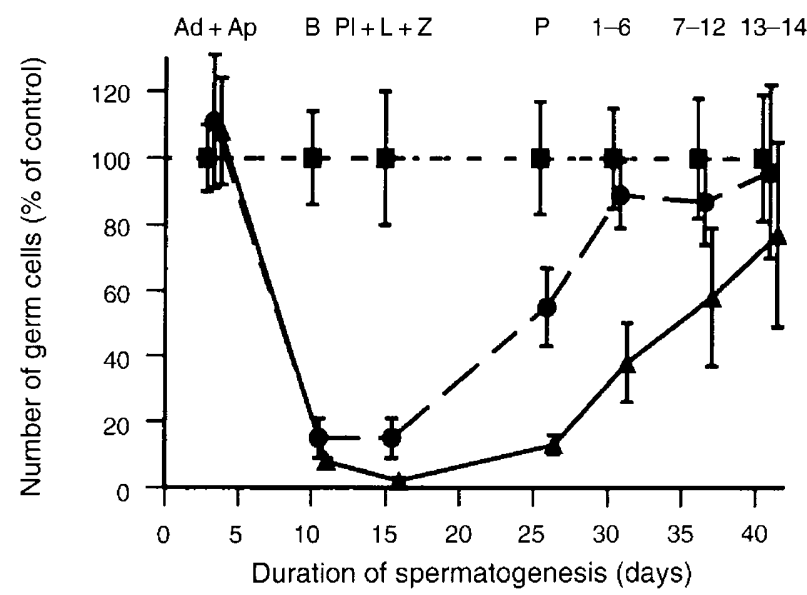

Fig. 2. Numbers of germ cells (expressed as percentage of control; in macaques receiving GnRH antagonist for 16 days (O) or 25 days $(\Delta)$. For the purposes of illustration, the $x$ axis has been scaled to reflect the duration of each stage of seminiferous epithelium (Fouquet and Dadoune, 1986).

\section{Discussion}

This study demonstrates that the key spermatogenic lesion resulting from acute GnRH-A induced gonadotrophin withdrawal is a profound reduction in number of type B spermatogonia, probably as a result of the inhibition of Ap spermatogonial mitosis. No significant impairment in germ cell development at later stages was detected, and the progressive loss of spermatocytes and spermatids was consistent with the dynamics of spermatogenesis after the type $A p \rightarrow B$ spermatogonial interruption. As a consequence in the long term, the seminiferous epithelium would be expected to contain only type A spermatogonia and Sertoli cells.

A regression of spermatogenesis to the level of type $A$ spermatogonia has been reported to occur after chronic hypophysectomy or GnRH-A treatment (Bremner et al., 1991; Marshall et al., 1986b; Weinbauer et al, 1991). There is controversy about the mechanism of this effect, which may result from a reduction in type Ap spermatogonial mitosis and/or from an increased loss of type B forms by apoptosis. The present data suggest that the mitotic activity of Ap spermatogonia is acutely reduced in response to gonadotrophin withdrawal. The frequency of the tubule stage was unchanged; however, the proportion of Ap spermatogonia in stages VII-XII decreased after GnRH-A treatment, suggesting that Ap spermatogonial mitosis was inhibited. This concept is consistent with the reported reduction in the mitotic activity of type A spermatogonia and other germ cells in monkeys treated chronically with GnRH-A, as assessed by proliferating cell nuclear antigen (PCNA) labelling (Schlatt and Weinbauer, 1994). The failure to observe a decline in total number of Ap spermatogonia does not preclude this interruption in their mitosis since, owing to interanimal variability, any possible decrease in number of Ap spermatogonia may not be detected readily. However, the interruption becomes apparent when the interanimal variability is controlled by calculating the proportion of Ap spermatogonia within each animal.

The question of whether gonadotrophins act on type Ap or $B$ spermatogonia has been addressed in several previous 

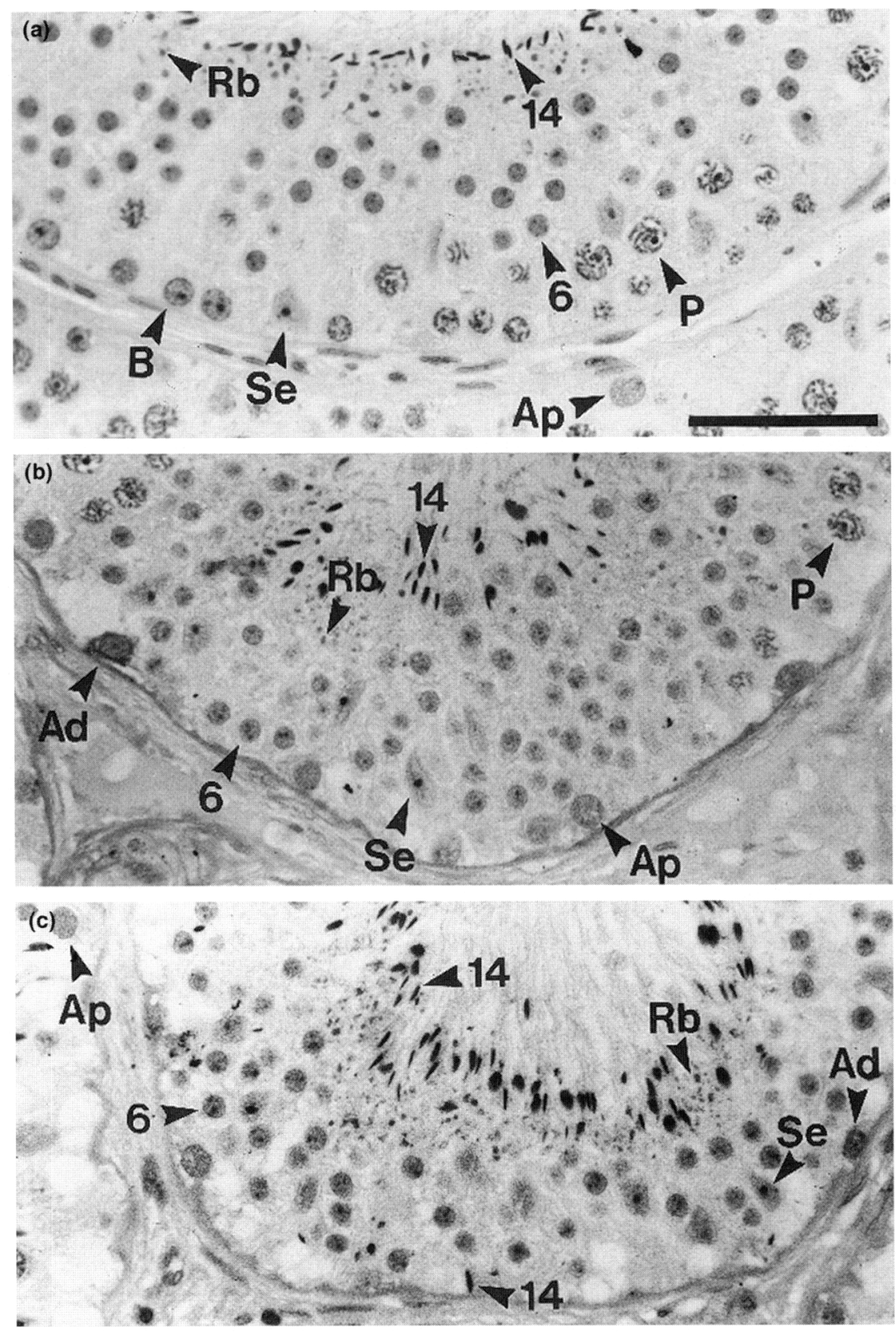

Fig. 3. Light micrographs of stage VI seminiferous epithelium from macaques receiving vehicle (a), or $\mathrm{GnRH}$ antagonist for 16 days (b) or 25 days (c). Ad, dark type A spermatogonia; Ap, pale type A spermatogonia; $B$, type B spermatogonia; $P$, pachytene primary spermatocyte; 6, step 6 spermatid; Rb, residual body; 14, step 14 spermatid; Se, Sertoli cell. Micrographs were taken with a $\times 40$ objective lens from $3 \mu \mathrm{m}$ thick methacrylate-embedded sections stained with PAS-haematoxylin. Scale bar represents $50 \mu \mathrm{m}$.

studies. Weinbauer et al. (1991) reported an effect of FSH treatment to maintain the number of Ap spermatogonia in animais co-administered GnRH-A for 28 days; however, no earlier time points were given. In normal animals given exogenous FSH for 7-28 days, the number of Ap spermatogonia was also reported to increase (van Alphen et al., 1988). In both these studies, the method of germ cell quantitation (germ cell: Sertoli cell ratios) used was subject to bias of unknown direction and magnitude. For example, in rats (McLachlan et al.,
1995) and in macaques in the present study, there was a substantial reduction in Sertoli cell nuclear volume after $\mathrm{GnRH}$ withdrawal, a factor that would introduce significant errors into such an approach.

Marshall et al. (1995) reported a stimulatory effect of FSH on type B spermatogonia (described in terms of germ cells per tubule cross-section), while numbers of Ap spermatogonia were unchanged after 12 days of FSH treatment in chronically hypophysectomized monkeys. Although numbers of Ap 

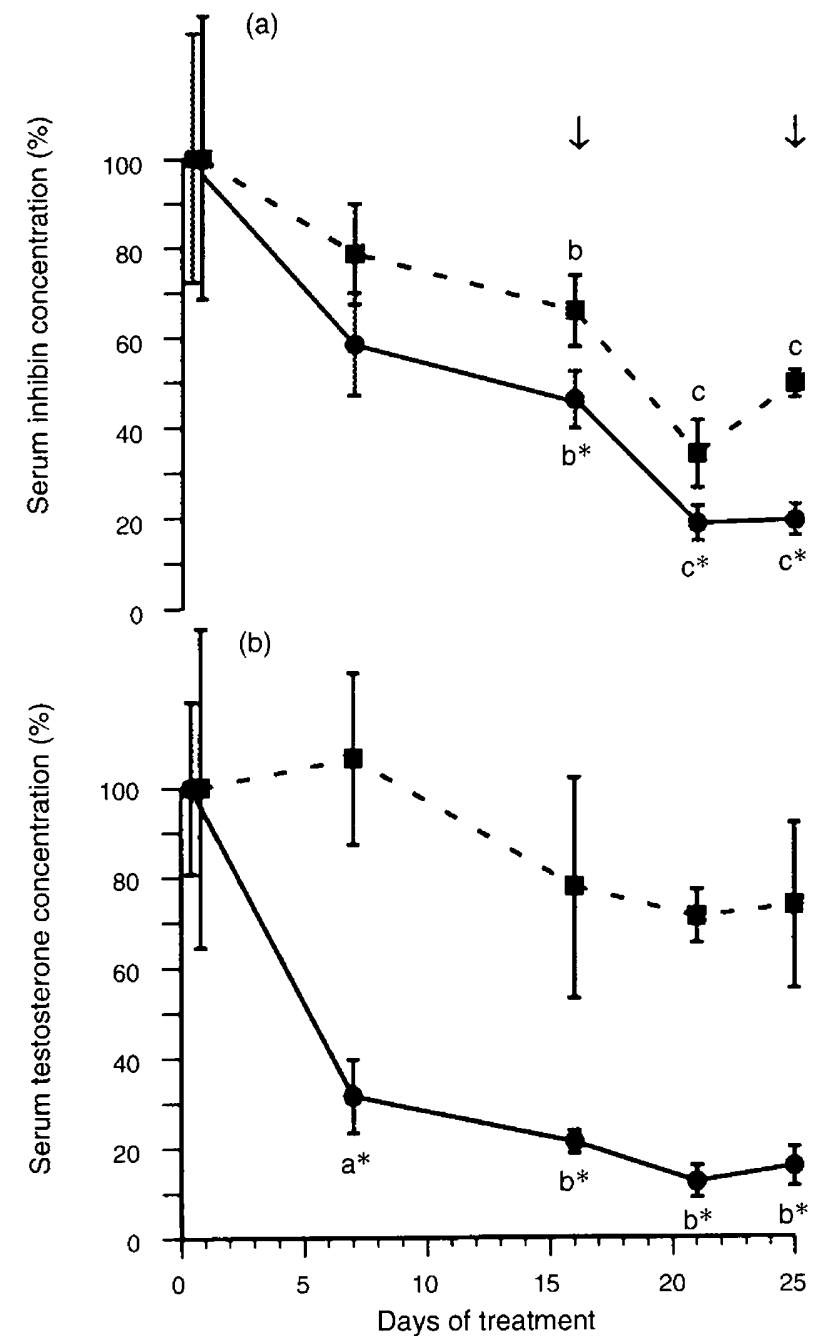

Fig. 4. Serum (a) inhibin and (b) testosterone concentrations in vehicle-treated ( $\mathbf{G}$ ) and GnRH-A-treated (O) macaques. Two pretreatment samples were taken from each animal and subsequent values were expressed as a percentage of the mean of these two samples. Blood samples on days 16 and 25 were taken immediately before the hemicastrations (arrows). ${ }^{a} P<0.05$ compared with pretreatment value; ${ }^{\mathrm{b}} \mathrm{P}<0.05$ compared with pretreatment and day 7 concentrations; ${ }^{c} P<0.05$ compared with pretreatment, day 7 and day 16 concentrations; ${ }^{*} P<0.05$ compared with vehicle-treated group at the same time point.

spermatogonia were considered within individual stages, there was a consistent increase in numbers of Ap spermatogonia at all 12 stages, an observation most unlikely to have arisen by chance if these variations in number were truly random. In addition, Marshall et al. (1995) failed to observe an increase in number of leptotene spermatocytes or later germ cells after 12 days of FSH treatment, as would have been expected if FSH acted on type B forms. They were forced to conclude that 'the dynamics of FSH action' were different from those in normal animals. The alternative possibility, that FSH acted on Ap spermatogonia, is consistent with their cell changes and the present data.

The dynamics of spermatogenic regression after GnRH-A treatment in the present study are consistent with the inhi- bition of division of Ap spermatogonia. According to the model of the primate seminiferous cycle (Clermont, 1969; Clermont and Antar, 1973; Fouquet and Dadoune, 1986), if the maturation of Ap spermatogonia to B spermatogonia was immediately interrupted while other cells continued to develop normally then, by day 16 , all type $B$ spermatogonia and preleptotene + leptotene + zygotene spermatocytes would have disappeared, and pachytene spermatocytes would be reduced to $62 \%$ of control, with no effects on later cell types. By day 25 , the model predicts that spermatocytes would have disappeared and that step 1-6 round spermatids would be reduced to approximately $66 \%$ of control. The present day 16 data are broadly consistent with this hypothesis with numbers of type B spermatogonia, preleptotene + leptotene + zygotene spermatocytes and pachytene spermatocyte being 15\%, 15\% and $55 \%$ of control, respectively. By day 25 , a few type B spermatogonia ( $8 \%$ control) and pachytene spermatocytes ( $13 \%$ control) persisted, while round spermatids were reduced to $38 \%$ of control. Overall, this rigorous method of assessing germ cell dynamics is consistent with a lesion at the type $A p \rightarrow B$ spermatogonial transition. Furthermore, the continued progression of later germ cell types, despite GnRH-A treatment, was suggested by the finding of a considerable number of secondary spermatocytes (including meiotic figures) and the presence of late (step 13-14) spermatids.

The relative importance of the withdrawal of FSH compared with androgens cannot be addressed directly by the present study. Serum FSH was not measured as there is no immuno- or bioassay available for the reliable measurement of normal or subnormal FSH concentrations in male macaques. Nonetheless, it is suggested that FSH concentrations were substantially reduced because (i) the high dose of GnRH-A would be expected to markedly reduce serum FSH concentrations on the basis of dose-response studies in castrated animals (Weinbauer and Nieschlag, 1993), and (ii) the extent of suppression of serum inhibin concentrations (to $38 \%$ of control) was of a similar degree to that seen in hypophysectomized animals $(46 \%$ control; Fingscheidt et al., 1989).

Serum testosterone concentrations were reduced to those seen in castrated animals (approximately $3 \mathrm{nmol} \mathrm{l}^{-1}$ ), indicating that serum $\mathrm{LH}$ concentrations were markedly reduced. However, testicular testosterone concentrations were suppressed to a mean of $21-36 \%$ of control by GnRH-A, although the wide variances may have accounted for the failure of this fall to achieve statistical significance. These testicular testosterone concentrations were consistently in excess of those measured in serum. Persistence of testicular testosterone (at approximately $35 \%$ of control) has been reported in chronically GnRH-A-treated (Weinbauer et al., 1988) or hypophysectomized (Marshall et al., 1986b) cynomolgus monkeys, despite serum testosterone concentrations in the castrate range. The basis of this disproportionately greater reduction in serum than in testicular testosterone concentrations, and the persistence of relatively high concentrations of testicular testosterone after gonadotrophin withdrawal, is unclear. It is possible that LH concentrations are not completely suppressed in GnRH-Atreated animals or that adult Leydig cells, unlike those from immature animals, produce testosterone constitutively (Sharpe, 1994). 
Serum inhibin concentrations fell before hemicastration in control animals; the reason for this decline is unclear but may relate to experimental stress. Inhibin concentrations were lower in GnRH-A-treated animals than in controls at each time point and, on day 25, fell to concentrations seen after hypophysectomy (Fingscheidt et al., 1989).

Differences are apparent in the spermatogenic response to gonadotrophin withdrawal in primates and rats, perhaps in part due to differences in the experimental paradigms and the endocrine responses to treatment. For example, serum FSH concentrations in rats are maintained in testosterone-treated intact rats (despite suppressed LH concentrations: O'Donnell et al., 1994), and are restored by exogenous testosterone in the GnRH-immunized rat (McLachlan et al., 1994a), suggesting that testosterone acts directly on the pituitary to restore FSH secretion by GnRH-independent mechanisms. However, in men, serum FSH concentrations were reduced to undetectable concentrations within 4 weeks of testosterone enanthate treatment (Andersen and $W u, 1996$ ). If a similar reduction in FSH occurs in testosterone-treated monkeys, a more marked and rapid regression would be expected in monkeys than in rats. However, with regard to androgen withdrawal, testicular testosterone concentrations fall to approximately $5 \%$ of control within 1 week after GnRH-A treatment in rats (SinhaHikim and Swerdloff, 1993), while the decline is far less (approximately 30\% control) in GnRH-A-treated or hypophysectomized monkeys (Marshall et al., 1986b; Weinbauer et al., 1988).

Multiple defects in spermatogenesis after gonadotrophin withdrawal have been demonstrated using a range of endocrine manipulations in rats, including defects in spermatocyte development, meiotic efficiency and, particularly, in maturation from round to elongated spermatids (Sinha-Hikim and Swerdloff, 1993; McLachlan et al., 1994a, b, 1995; O'Donnell et al., 1994; Singh et al., 1995). In particular reference to spermiogenesis, a marked reduction in late spermatids was seen in rats within 2 weeks of GnRH-A treatment (Sinha-Hikim and Swerdloff, 1993). The conversion of step 7 to step 8 spermatids was significantly reduced within 3 weeks of testosterone treatment despite the maintenance of serum FSH (O'Donnell et al., 1996). However, in the present primate study, even at 25 days of GnRH-A treatment, the progression from round to elongated spermatids was maintained. A possible explanation for this finding is that, despite the likely marked FSH deficiency, the persistence of testicular testosterone concentrations at approximately $30 \%$ of control in primates supports a number of events, including meiosis and spermiogenesis, both of which are androgen-dependent, using rat models (Sharpe, 1994; McLachlan et al., 1996). In contrast, in GnRH-A-treated rats, testicular testosterone concentrations fall more quickly and markedly (Sinha-Hikim and Swerdloff, 1993), perhaps facilitating the more extensive spermatogenic disruption. A systematic comparison of rats and primates after GnRH-A administration is needed to clarify the true extent of species-related differences in response.

A further difference may be in the regulation of spermatogonial mitosis. Spermatogonial mitosis, as determined using the PCNA technique, still occurred in GnRH-A-treated (for 6 weeks) rats, whereas it was markedly reduced after 8 weeks of GnRH-A treatment in monkeys (Schlatt and Weinbauer,
1994). When exogenous FSH and hCG were used to stimulate spermatogenesis in immature monkeys, FSH increased spermatogonial mitosis, yet was unable to permit further germ cell development without the concomitant increase in testicular testosterone concentrations (Schlatt et al., 1995).

In conclusion, an unbiased stereological technique was used to demonstrate that the principal lesion in primate spermatogenesis is the rapid and profound reduction in number of type B spermatogonia, and suggests that the primary mechanism of this reduction is the inhibition of Ap spermatogonial mitosis. Later germ cell development, specifically meiosis and spermiogenesis, appears to proceed unaffected. The fact that testicular testosterone concentrations were not profoundly reduced in the face of such marked spermatogenic disruption suggests a critical role for FSH in the maintenance of primate spermatogenesis. Further definition of the roles of FSH and LH/testosterone depends on the development of more sensitive monkey gonadotrophin assays applicable to gonadotrophin-deficient animals. The use of well characterized in vivo models, together with robust and unbiased germ cell counting procedures, can be further applied in understanding the mechanism of FSH action and in the study of contraceptive strategies.

The authors are grateful to S. Forsthoff, M. Heuermann, R. Sandhowe and G. Stelke for their excellent technical assistance. This study was supported by the Contraception 21 Grant of the Rockefeller Foundation, the Australian NH\&MRC Program Grant 943208, Australian Research Council Grant 80900657, and the NIH RP 00166 , and the Deutsche Forschungsgemeinschaft Grant Ni-130/15-I. S. Schlatt is a recipient of a training fellowship from the Deutsche Forschungsgemeinschaft (Schl 394/1-1).

\section{References}

Adams LA, Bremner WJ, Nestor JJ, Jr, Vickery BH and Steiner RA (1986) Suppression of plasma gonadotrophins and testosterone in adult male monkeys (Macaca fascicularis) by a potent inhibitory analog of gonadotrophin-releasing hormone Journal of Clinical Endocrinology and Metabolism 62 58-63

Akhtar FB, Weinbauer GF and Nieschlag E (1985) Acute and chronic effects of a gonadotrophin-releasing hormone antagonist on pituitary and testicular function in monkeys Journal of Endocrinology 104 345-354

Andersen RA and $\mathrm{Wu}$ FCW (1996) Comparison between testosterone enanthate-induced azoospermia and oligozoospermia in a male contraceptive study. II. Pharmacokinetics and pharmacodynamics of once weekly administration of testosterone enanthate Journal of Clinical Endocrinology and Metabolism 81 896-901

Baddeley AJ, Gundersen HJG and Cruz-Orive LM (1986) Estimation of surface area from vertical sections Journal of Microscopy 142 259-276

Bagatell CJ, Matsumoto AM, Christensen RB, Rivier JE and Bremner WJ (1993) Comparison of a gonadotrophin releasing hormone antagonist plus testosterone $(T)$ versus $T$ alone as potential male contraceptive regimens Journal of Clinical Endocrinology and Metabolism 77 427-432

Bremner WJ, Bagatell CJ and Steiner RA (1991) Gonadotropin-releasing hormone antagonist plus testosterone: a potential male contraceptive Journal of Clinical Endocrinology and Metabolism 73 465-469

Chandolia RK, Weinbauer GF, Simoni M, Behre HM and Nieschlag E (1991) Comparative effects of chronic administration of the non-steroidal antiandrogens flutamide and casodex on the reproductive system of the adult male rat Acta Endocrinologica 125 547-555

Clermont Y (1969) Two classes of spermatogonial stem cells in the monkey (Cercopithecus aethiops) American Journal of Anatomy 126 57-72

Clermont $\mathrm{Y}$ and Antar M (1973) Duration of the cycle of the seminiferous epithelium and the spermatogonial renewal in the monkey Macaca arctoides. American Journal of Anatomy $136 \quad 153-166$ 
Clermont $\mathrm{Y}$ and Leblond CP (1955) Spermiogenesis of man, monkey, ram and other mammals as shown by the 'periodic acid-Schiff' technique American Journal of Anatomy 96 229-253

Clermont $Y$ and Leblond CP (1959) Differentiation and renewal of spermatogonia in the monkey, Macacus rhesus. American Journal of Anatomy 104 $237-273$

Fingscheidt U, Weinbauer GF, Robertson DM, de Kretser DM and Nieschlag E (1989) Radioimmunoassay of inhibin in the serum of male monkeys Journal of Endocrinology 122 477-483

Fouquet JP and Dadoune JP (1986) Renewal of spermatogonia in the monkey (Macaca fascicularis) Biology of Reproduction 35 199-207

Gundersen HJG (1977) Notes on the estimation of the numerical density of arbitrary profiles: the edge effect Journal of Microscopy 111 219-223

Gundersen HJG, Bagger P, Bendsten TF, Evans SM, Korbo L, Marcussen N, Moller A, Nielsen K, Nyengaard JR, Pakkenberg B, Sorensen FB, Vesterby A and West MJ (1988a) The new stereological tools: disector, fractionator, nucleator and point sampled intercepts and their use in pathological research and diagnosis APMIS 96 857-881

Gundersen HJG, Bendsten TF, Korbo L, Marcussen N, Moller A, Nielsen K, Nyengaard JR, Pakkenberg B, Sorensen FB, Vesterby A and West MJ (1988b) Some new, simple and efficient stereological methods and their use in pathological research and diagnosis APMIS 96 379-394

Jensen EB and Gundersen HJG (1993) The rotator Journal of Microscopy 170 $35-44$

Kangasniemi M, Wilson G, Parchuri N, Huhtaniemi I and Meistrich ML (1995) Rapid protection of rat spermatogenic stem cells against procarbazine by treatment with a gonadotrophin-releasing hormone antagonist (Nal-Glu) and an antiandrogen (flutamide) Endocrinology 136 2881-2888

Kumar TR, Wang Y, Lu N, Matzuk, MM (1997) Follicle stimulating hormone is required for ovarian follicle maturation but not male fertility Nature Genetics 15 (2) 201-204

Marshall GR, Akhtar FB, Weinbauer GF and Nieschlag E (1986a) Gonadotrophinreleasing hormone ( $\mathrm{GnRH}$ ) overcomes $\mathrm{GnRH}$ antagonist-induced suppression of LH secretion in primates Journal of Endocrinology 110 145-150

Marshall GR, Jockenhövel F, Lüdecke D and Nieschlag E (1986b) Maintenance of complete but quantitatively reduced spermatogenesis in hypophysectomized monkeys by testosterone alone Acta Endocrinologica 113 424-431

Marshall GR, Zorub DS and Plant TM (1995) Follicle-stimulating hormone amplifies the population of differentiated spermatogonia in the hypophysectomized testosterone-replaced adult rhesus monkey (Macaca mulatta) Endocrinology 136 3504-3511

Matsumoto AM, Karpas AE, Bremner WJ (1986) Chronic hCG administration in normal men: evidence that FSH is necessary for the maintenance of quantitatively normal spermatogenesis in man Journal of Clinical Endocrinology and Metabolism 62 1184-1192.

McLachlan RI, Wreford NG, Tsonis C, de Kretser DM and Robertson DM (1994a) Testosterone effects on spermatogenesis in the gonadotrophin-releasing hormone-immunized rat Biology of Reproduction 50 271-280

McLachlan RI, Wreford NG, Meachem SJ, de Kretser DM and Robertson DM (1994b) Effects of testosterone on spermatogenic cell populations in the adult rat Biology of Reproduction 51 945-955

McLachlan RI, Wreford NG, de Kretser DM and Robertson DM (1995) The effects of recombinant FSH on the restoration of spermatogenesis in the gonadotrophin-releasing hormone-immunized adult rat Endocrinology 136 4035-4043

McLachlan RI, Wreford NG, O'Donnell L, de Kretser DM and Robertson DM (1996) The endocrine regulation of spermatogenesis: independent roles for testosterone and FSH Journal of Endocrinology 148 1-9

Meachem SJ, McLachlan RI, de Kretser DM, Robertson DM and Wreford NG (1996) Neonatal exposure of rats to recombinant follicle stimulating hormone increases adult Sertoli and spermatogenic cell numbers Biology of Reproduction 54 36-44

O'Donnell L, McLachlan RI, Wreford NG and Robertson DM (1994) Testosterone promotes the conversion of round spermatids between stages VII and VIII of the rat spermatogenic cycle Endocrinology 135 2608-2614

O'Donnell L, McLachlan RI, Wreford NG, de Kretser DM and Robertson DM (1996) Testosterone withdrawal promotes stage-specific detachment of round spermatids from the rat seminiferous epithelium Biology of Reproduction 55 895-901

Schlatt S and Weinbauer GE (1994) Immunohistochemical localization of proliferating cell nuclear antigen as a tool to study cell proliferation in rodent and primate testes International Journal of Andrology 17 214-222
Schlatt S, Arslan M, Weinbauer GF, Behre HM and Nieschlag E (1995) Endocrine control of testicular somatic and premeiotic germ cell development in the immature testis of the primate Macaca mulatta. European Journal of Endocrinology $133235-247$

Sharpe RM (1994) Regulation of spermatogenesis. In The Physiology of Reproduction pp 1363-1434 Eds E Knobil and JD Neill. Raven Press, New York

Singh J, O'Neill and Handelsman DJ (1995) Induction of spermatogenesis by androgens in gonadotrophin-deficient (hpg) mice Endocrinology 136 $5311-5321$

Sinha-Hikim AP and Swerdloff RS (1993) Temporal and stage-specific changes in spermatogenesis of rat after gonadotrophin deprivation by a potent gonadotrophin-releasing hormone antagonist treatment Endocrinology 133 2161-2170

Smith PE (1930) Hypophysectomy and a replacement therapy in the rat American journal of Anatomy 45 205-256

Smith PE (1944) Effect of equine gonadotrophin on testes of hypophysectomized monkeys Endocrinology 31 1-12

Sterio DC (1984) The unbiased estimation of number and sizes of arbitrary particles using the disector Journal of Microscopy 134 127-136

Tapanainen IS, Aittomaki K, Min J, Vaskivuo T, Huhtaniemi IT (1997) Men homozygous for an inactivating mutation of the follicle-stimulating hormone receptor gene present variable suppression of spermatogenesis and fertility Nature Genetics 15 205-206

van Alphen MAA, van de Kant HJG and de Rooij DG (1988) Follicle-stimulating hormone stimulates spermatogenesis in the adult monkey Endocrinology $\mathbf{1 2 3}$ 1449-1455

Weinbauer GF and Nieschlag E (1985) Regulation of primate testicular function by $\mathrm{GnRH}$ analogues Medical Biology 63 210-217

Weinbauer GF and Nieschlag E (1993) Comparison of the antigonadotropic activity of three GnRH antagonists (Nal-Glu, Antide and Cetrorelix) in a non-human primate model (Macaca fascicularis) Andrologia 25 141-147

Weinbauer GF, Surmann FJ, Akhtar FB, Shah GV, Vickery BH and Nieschlag E (1984) Reversible inhibition of testicular function by a gonadotrophin hormone-releasing hormone antagonist in monkeys (Macaca fascicularis) Fertility and Sterility 42 906-914

Weinbauer GF, Surmann FJ and Nieschlag E (1987) Suppression of spermatogenesis in a non human primate (Macaca fascicularis) by concomitant gonadotrophin-releasing hormone antagonist and testosterone treatment Acta Endocrinologica 114 138-146

Weinbauer GF, Göckeler E and Nieschlag E (1988) Testosterone prevents complete suppression of spermatogenesis in the gonadotrophin-releasing hormone antagonist-treated non human primate (Macaca fascicularis) Journal of Clinical Endocrinology and Metabolism 67 284-290

Weinbauer GF, Khurshid S, Fingscheidt U and Nieschlag E (1989) Sustained inhibition of sperm production and inhibin secretion induced by a gonadotrophin-releasing hormone antagonist and delayed testosterone substitution in non-human primates (Macaca fascicularis) Journal of Endocrinology 123 303-310

Weinbauer GF, Behre HM, Fingscheidt U and Nieschlag E (1991) Human follicle-stimulating hormone exerts a stimulatory effect on spermatogenesis, testicular size, and serum inhibin levels in the gonadotrophin-releasing hormone antagonist-treated non-human primate (Macaca fascicularis) Endocrinology 129 1831-1839

Weinbauer GF, Hankel P and Nieschlag E (1992) Exogenous gonadotrophinreleasing hormone $(\mathrm{GnRH})$ stimulates $\mathrm{LH}$ secretion in male monkeys (Macaca fascicularis) treated chronically with high doses of a GnRH antagonist Journal of Endocrinology 133 439-445

Weinbauer GF, Limberger A, Behre HM and Nieschlag E (1994) Can testosterone alone maintain the gonadotrophin-releasing hormone antagonist-induced suppression of spermatogenesis in the non-human primate journal of Endocrinology 142 485-495

Weinbauer GF, Schubert J, Yeung C-H, Rosiepen G and Nieschlag E Gonadotrophin-releasing hormone $(\mathrm{GnRH})$ antagonist arrests premeiotic germ cell proliferation but does not inhibit meiosis in the male monkey: a quantitative analysis using 5-bromodeoxyuridine and dual parameter flow cytometry Journal of Endocrinology (in press)

WHO Task Force on Methods for the Regulation of Male Fertility (1990) Contraceptive efficacy of testosterone-induced azoospermia in normal men Lancet $336955-959$

Wreford NG (1995) Theory and practice of stereological techniques applied to the estimation of cell number and nuclear volume in the testis Microscopy Research and Technique 32 423-436 